Eur J Clin Chem Clin Biochem

1995; 33:225-229

(c) 1995 Walter de Gruyter \& Co.

Berlin · New York

\title{
Haemostasis Activation Markers in Plasma of Patients with Benign and Malignant Gynaecological Tumours: A Pilot Study
}

\author{
By Jan W. J. van Wersch ${ }^{1}$, Claire Peters ${ }^{2}$ and Hans M. H. Ubachs ${ }^{2}$ \\ 1 Department of Haematology \\ 2 Department of Gynaecology \\ De Wever Hospital, Heerlen, The Netherlands
}

(Received October 19, 1994/February 6, 1995)

Summary: Coagulation and fibrinolysis activation have been investigated in fifty-eight women with recently detected gynaecological tumours. Twenty-six were benign and 32 malignant: of the last group nine patients had metastases. A control group consisted of 31 age-matched healthy women. Prothrombin fragment $1+2$, thrombinantithrombin III and D-dimer were measured. The median values of all analytes were significantly higher in the malignant tumour group, but not in the benign tumour group, as compared to the control group. The group of patients with a gynaecological tumour and metastases differed from the non-metastasized tumour group in prothrombin fragment $1+2$, thrombin-antithrombin III and D-dimer. In the non-metastasized malignant tumour group solely prothrombin fragment $1+2$ was significantly higher than in the benign tumour group. Coagulation and fibrinolysis appeared to be activated in the patients with a metastasized gynaecological tumour, fibrinolysis predominating as can be derived from the elevated D-dimer/thrombin-antithrombin III and D-dimer/prothrombin fragment $1+2$ ratios. The studied constituents do not enable a differentiation between the benign and malignant processes. However, as the differences of these values in both malignant tumour groups were significant, this might be used to trace the existence of metastases in gynaecological tumours. Investigation of these analytes in several specific types of gynaecological tumours might be clinically relevant.

\section{Introduction}

Activation of coagulation and fibrinolyis has been demonstrated in several cancer types $(1-5)$, sometimes accompanied by overt bleeding or thrombosis even in patients without metastasis, necrosis or inflammation (6). Much effort has been made to identify procoagulants on tumour cells themselves (7), as a wide variety of these cells induce local fibrin deposition by increasing microvascular permeability and by clotting extravasated fibrinogen (2). An increase in fibrinolytic activity has been observed in patients with metastases and evidence of disseminated intravascular coagulation (8).

Thromboembolism can be demonstrated at autopsy in 50 percent of all cancer patients although at most 10 percent of these patients actually have significant clinical signs of thrombosis (9). Episodes of haemorrhage may occur in patients with tumour invasion (10). Routine blood coagulation tests display abnormalities in up to $92 \%$ of patients with cancer, although this percentage varies with the distinct types of malignancy $(11,12)$. Little is known about the haemostatic behaviour of patients with gynaecological cancer. Examination of fibrin degradation products has only been presented for patients with ovarian tumours in the early seventies for diagnostic and follow-up reasons $(13,14)$. Therefore, in the present study the balance between coagulation and fibrinolysis markers was investigated in patients with benign and malignant gynaecological tumours. Coagulation activation was measured by the sensitive clotting turnover products thrombin-antithrombin III complex and prothrombin fragments $1+2$. The fibrinolytic system was evaluated by measuring $D$-dimer. 


\begin{abstract}
Materials and Methods
Patients

Plasma samples were collected from 58 patients with suspicion of a benign or malignant gynaecological tumour and subsequent diagnostic confirmation by histology. On admission to the hospital no patient showed clinical signs of bleeding or thrombosis. Tiventy-six patients had a benign disease (tab. 1) and 32 patients a malignancy (tab. 2). In the latter group nine patients had metastases histologically proven mostly in lymph nodes or peritoneal tissue. The use of medication was excluded. A reference group consisted of 31 age-matched ostensibly healthy women.
\end{abstract}

\section{Samples}

Blood samples were drawn between 8.30 and 9.00 a. m. after fasting overnight for $10 \mathrm{~h}$ and a resting period of $20 \mathrm{~min}$.

The various constituents were determined in citrated plasma. This was prepared by centrifugation of a mixture of nine volumes freshly drawn blood with one volume trisodium citrate $(0.11 \mathrm{~mol} / \mathrm{l})$ during $30 \mathrm{~min}(1600 \mathrm{~g})$ at $25^{\circ} \mathrm{C}$. The plasma was stored at $-70^{\circ} \mathrm{C}$ in plastic tubes and thawed at $37^{\circ} \mathrm{C}$ for $5 \mathrm{~min}$ before batch analysis.

\section{Methods}

The prothrombin fragment $1+2$ test was determined with an ELISA test kit (Behring Corporation, Marburg, Germany). For the thrombin-antithrombin III determination an ELISA test kit was used (Behring, Marburg, Germany). The fibrin degradation products were measured by means of the D-dimer test of BoehringerMannheim (Mannheim, Germany). The D-dimer/thrombinantithrombin III and the D-dimer/prothrombin fragment $1+2$ ratio were calculated on molar basis as arbitrary measures of the fibrinolysis/coagulation balance.

The Mann-Whitney $U$ test and the $\chi^{2}$-test, where appropriate, were used for statistical analysis.

\section{Results}

In table 1 the diagnoses of the patients with a benign disease are given. Ovarian cysts occur most in this group.

Table 2 shows the various tumour types in the patients with a malignancy. Most of the patients appeared to have a cervix or an ovarian carcinoma. Metastases were especially present in the ovarian carcinoma group.

In table 3 a comparison of the benign tumour group, the total malignant and an age-matched control group is given. Except for the age, all of the test results showed

Tab. 1 Diagnoses of the benign tumour group.

\begin{tabular}{lc}
\hline Benign tumour type & Patients \\
\hline Ovarian/adnex cyst & 15 \\
Ovarian fibroma & 3 \\
Ovarian cyst and myoma uteri & 2 \\
Endometrioma & 2 \\
Myoma uteri & 2 \\
Cyst of unknown origin & 2 \\
\hline
\end{tabular}

Tab. 2 Diagnoses and metastasis status of the malignant tumour group.

\begin{tabular}{lccl}
\hline $\begin{array}{l}\text { Malignant } \\
\text { tumour } \\
\text { type }\end{array}$ & $\begin{array}{l}\text { All } \\
\text { patients }\end{array}$ & $\begin{array}{l}\text { Patients } \\
\text { without } \\
\text { metastases }\end{array}$ & $\begin{array}{l}\text { Patients } \\
\text { with } \\
\text { metastases }\end{array}$ \\
\hline Carcinoma cervicis & 12 & 11 & 1 \\
Ovarian carcinoma & 10 & 3 & 7 \\
Endometrium carcinoma & 6 & 6 & 0 \\
Carcinoma of vulva & 2 & 2 & 0 \\
Leiomyosarcoma uteri & 1 & 1 & 0 \\
Sarcoma uteri & 1 & 0 & 1 \\
\hline
\end{tabular}

a non-Gaussian distribution, and the results are presented as median values and interquartile ranges. The group with a benign gynaecological tumour showed statistically significant higher median values of $D$-dimer/ thrombin-antithrombin III ratio in comparison with the age-matched control group. Comparing the malignant tumour group and the age-matched control group, statistically significantly increased median values were found for prothrombin fragment $1+2$, D-dimer and D-dimer/ thrombin-antithrombin III ratio.

In table 4 patients of the malignant group with and without metastases are compared with the benign tumour group. The values of prothrombin fragment $1+2$, thrombin-antithrombin III, D-dimer, D-dimer/thrombinantithrombin III ratio and D-dimer/prothrombin fragment $1+2$ ratio were significantly increased in the group with metastases.

Table 5 gives the percentages of decreased and increased values of the various coagulation and fibrinolysis constituents in the three patient groups based on the laboratory reference ranges.

Between the benign and the non-metastatic tumour group significantly different proportions of increased values were found for prothrombin fragment $1+2$ and for $\mathrm{D}$-dimer. The percentages of increased values between the non-metastatic and metastatic tumour groups were significantly different for thrombin-antithrombin III and D-dimer.

\section{Discussion}

The patients with a benign gynaecological tumour did not differ significantly in comparison with the control group with the exception of the D-dimer/thrombinantithrombin ratio. The malignant tumour group however showed, compared to the control group, significant differences for all measured quantities. Subdivision of the malignant tumour. group in a group with 
and a group without metastases revealed that the deviations in the total malignant tumour group were mainly due to the patients with metastases.
The results reflect a substantial activation of blood coagulation (prothrombin fragment $1+2$, thrombinantithrombin III) with reactive fibrinolysis (D-dimer).

Tab. 3 Comparison of the benign and malignant tumour groups with an age-matched control group.

\begin{tabular}{|c|c|c|c|c|c|c|}
\hline \multirow{3}{*}{. } & \multirow{3}{*}{$\begin{array}{l}\text { Patients } \\
\text { with benign } \\
\text { gynaecological } \\
\text { tumour } \\
\text { (G1) } \\
\text { Median } \\
\text { ( } 25-75 \\
\text { percentiles) }\end{array}$} & \multirow{3}{*}{$\begin{array}{l}\text { Patients } \\
\text { with malignant } \\
\text { gynaecological } \\
\text { tumour } \\
\text { (G2) } \\
\text { Median } \\
\text { (25-75 } \\
\text { percentiles) }\end{array}$} & \multirow{3}{*}{$\begin{array}{l}\text { Age } \\
\text { matched } \\
\text { control } \\
\text { group } \\
\text { (G3) } \\
\text { Median } \\
\text { (25-75 } \\
\text { percentiles) }\end{array}$} & \multicolumn{3}{|c|}{$\begin{array}{l}\text { Significance } \\
\text { p-value }\end{array}$} \\
\hline & & & & \multirow[t]{2}{*}{ G1 vs $G 2$} & \multirow[t]{2}{*}{ G1 vs G3 } & \multirow[t]{2}{*}{$\mathrm{G} 2$ vs $\mathrm{G} 3$} \\
\hline & & & & & & \\
\hline Number & 26 & 32 & 31 & - & - & - \\
\hline Age & $\begin{array}{l}53 \\
(46-65)\end{array}$ & $\begin{array}{l}57 \\
(48-68)\end{array}$ & $\begin{array}{l}51 \\
(49-54)\end{array}$ & n.s. & n.s. & n.s. \\
\hline $\begin{array}{l}\text { Prothrombin fragment } 1+2 \\
\quad(\mathrm{nmol} / \mathrm{l})\end{array}$ & $\begin{array}{l}1.00 \\
(0.86-1.50)\end{array}$ & $\begin{array}{l}1.50 \\
(1.23-1.95)\end{array}$ & $\begin{array}{l}1.10 \\
(0.84-1.35)\end{array}$ & 0.001 & n.s. & 0.001 \\
\hline $\begin{array}{l}\text { Thrombin-antithrombin III } \\
(\mu \mathrm{g} / \mathrm{l})\end{array}$ & $\begin{array}{l}2.5 \\
(1.8-3.9)\end{array}$ & $\begin{array}{l}3.3 \\
(2.4-8.3)\end{array}$ & $\begin{array}{l}2.3 \\
(2.0-3.2)\end{array}$ & 0.007 & n.s. & 0.03 \\
\hline $\begin{array}{l}\text { D-dimer } \\
(\mu g / l)\end{array}$ & $\begin{array}{l}340 \\
(220-580)\end{array}$ & $\begin{array}{l}570 \\
(300-2138)\end{array}$ & $\begin{array}{l}240 \\
(200-360)\end{array}$ & 0.003 & n.s. & 0.0001 \\
\hline $\begin{array}{l}\text { D-dimer/thrombin- } \\
\text { antithrombin III ratio }\end{array}$ & $\begin{array}{l}77.3 \\
(66.6-156.2)\end{array}$ & $\begin{array}{l}108.8 \\
(76.0-199.8)\end{array}$ & $\begin{array}{l}66.1 \\
(37.5-78.8)\end{array}$ & n.s. & 0.047 & 0.0003 \\
\hline $\begin{array}{l}\text { D-dimer/prothrombin } \\
\text { fragment } 1+2 \text { ratio }\end{array}$ & $\begin{array}{l}1.6 \\
(1.3-4.2)\end{array}$ & $\begin{array}{l}2.3 \\
(1.6-6.7)\end{array}$ & $\begin{array}{l}1.4 \\
(1.2-2.1)\end{array}$ & $\begin{array}{l}\text { n. s. } \\
(0.058)\end{array}$ & n.s. & 0.003 \\
\hline
\end{tabular}

Tab. 4 Comparison of the malignant tumour groups with and without metastases, and the benign tumour group.

\begin{tabular}{|c|c|c|c|c|c|c|}
\hline & \multirow{2}{*}{$\begin{array}{l}\text { Patients } \\
\text { with benign } \\
\text { gynaecological } \\
\text { tumour }\end{array}$} & \multirow{2}{*}{$\begin{array}{l}\text { Patients } \\
\text { with malignant } \\
\text { gynaecologcial } \\
\text { tumour } \\
\text { without } \\
\text { metastases } \\
\text { (G2) }\end{array}$} & \multirow{2}{*}{$\begin{array}{l}\text { Patients } \\
\text { with malignant } \\
\text { gynaecological } \\
\text { tumour } \\
\text { and metastases } \\
\text { (G3) }\end{array}$} & \multicolumn{3}{|c|}{$\begin{array}{l}\text { Significance } \\
\text { p-value }\end{array}$} \\
\hline & & & & G1 vs $\mathrm{G} 2$ & G1 vs $\mathrm{G} 3$ & $\mathrm{G} 2$ vs $\mathrm{G} 3$ \\
\hline & $\begin{array}{l}\text { Median } \\
(25-75 \\
\text { percentiles })\end{array}$ & $\begin{array}{l}\text { Median } \\
(25-75 \\
\text { percentiles) }\end{array}$ & $\begin{array}{l}\text { Median } \\
(25-75 \\
\text { percentiles })\end{array}$ & & & \\
\hline Number & 26 & 23 & 9 & - & - & - \\
\hline Age & $\begin{array}{l}53 \\
(45-65)\end{array}$ & $\begin{array}{l}60 \\
(45-70)\end{array}$ & $\begin{array}{l}54 \\
(49-65)\end{array}$ & n.s. & n.s. & n.s. \\
\hline $\begin{array}{l}\text { Prothrombin fragment } 1+2 \\
\quad(\mathrm{nmol} / \mathrm{l})\end{array}$ & $\begin{array}{l}1.00 \\
(0.86-1.50)\end{array}$ & $\begin{array}{l}1.35 \\
(1.20-1.70)\end{array}$ & $\begin{array}{l}2.00 \\
(1.85-2.70)\end{array}$ & $<0.02$ & 0.002 & 0.03 \\
\hline $\begin{array}{l}\text { Thrombin-antithrombin III } \\
(\mu \mathrm{g} / \mathrm{l})\end{array}$ & $\begin{array}{l}2.5 \\
(1.8-3.9)\end{array}$ & $\begin{array}{l}2.6 \\
(2.0-3.6)\end{array}$ & $\begin{array}{l}8.5 \\
(6.4-10.0)\end{array}$ & n.s. & $<0.0001$ & 0.002 \\
\hline $\begin{array}{l}\text { D-dimer } \\
(\mu g / 1)\end{array}$ & $\begin{array}{l}340 \\
(220-580)\end{array}$ & $\begin{array}{l}420 \\
(270-680)\end{array}$ & $\begin{array}{l}5000 \\
(1375-6000)\end{array}$ & n.s. & $<0.0001$ & 0.0002 \\
\hline $\begin{array}{l}\text { D-dimer/thrombin- } \\
\text { antithrombin III ratio }\end{array}$ & $\begin{array}{l}77.3 \\
(66.6-156.2)\end{array}$ & $\begin{array}{l}84.5 \\
(71.2-125.8)\end{array}$ & $\begin{array}{l}236.7 \\
(160.2-348.4)\end{array}$ & n.s. & 0.003 & 0.003 \\
\hline $\begin{array}{l}\text { D-dimer/prothrombin } \\
\text { fragment } 1+2 \text { ratio }\end{array}$ & $\begin{array}{l}1.6 \\
(1.3-4.2)\end{array}$ & $\begin{array}{l}1.8 \\
(1.4-2.5)\end{array}$ & $\begin{array}{l}7.8 \\
(6.1-13.1)\end{array}$ & n.s. & 0.00005 & 0.0002 \\
\hline
\end{tabular}


Tab. 5 Percentage of decreased and increased values of various coagulation and fibrinolysis constituents based on laboratory reference ranges. The significant values are indicated $\left(\chi^{2}\right.$-test):

$$
\begin{aligned}
& \begin{array}{llll}
\text { 1) } p=0.001 ; & \text { 2) } \left.\left.p=0.001 ; \quad{ }^{3}\right) \mathrm{p}=0.026 ; \quad{ }^{4}\right) \mathrm{p}=0.045
\end{array} \\
& \left.\left.{ }^{5)} \mathrm{p}=0.002 ;{ }^{6}\right) \mathrm{p}=0.0005 ;{ }^{7}\right) \mathrm{p}=0.0034
\end{aligned}
$$

\begin{tabular}{|c|c|c|c|c|c|c|c|}
\hline & \multicolumn{2}{|c|}{$\begin{array}{l}\text { Patients } \\
\text { with benign } \\
\text { gynaecological } \\
\text { tumour } \\
\text { (GI) }\end{array}$} & \multicolumn{2}{|c|}{$\begin{array}{l}\text { Patients } \\
\text { with malignant } \\
\text { gynaecological tumour } \\
\text { without metastases } \\
\text { (G1) }\end{array}$} & \multicolumn{2}{|c|}{$\begin{array}{l}\text { Patients } \\
\text { with malignant } \\
\text { gynaecological tumour } \\
\text { and metastases } \\
\text { (G2) }\end{array}$} & \multirow[t]{2}{*}{$\begin{array}{l}\text { Laboratory } \\
\text { reference } \\
\text { range }\end{array}$} \\
\hline & $\begin{array}{l}\text { Decreased } \\
\text { values } \\
(\%)\end{array}$ & $\begin{array}{l}\text { Increased } \\
\text { values } \\
(\%)\end{array}$ & $\begin{array}{l}\text { Decreased } \\
\text { values } \\
(\%)\end{array}$ & $\begin{array}{l}\text { Increased } \\
\text { values } \\
(\%)\end{array}$ & $\begin{array}{l}\text { Decreased } \\
\text { values } \\
(\%)\end{array}$ & $\begin{array}{l}\text { Increased } \\
\text { values } \\
(\%)\end{array}$ & \\
\hline $\begin{array}{l}\text { Prothrombin } \\
\quad \text { fragment } 1+2\end{array}$ & 0 & $\left.\left.44.4^{1}\right),{ }^{2}\right)$ & 0 & $\left.87.0^{1}\right)$ & 0 & $88.9^{2}$ ) & $0.44-1.11 \mathrm{nmol} / \mathrm{I}$ \\
\hline $\begin{array}{l}\text { Thrombin- } \\
\text { antithrombin III }\end{array}$ & 0 & $\left.18.5^{3}\right)$ & 0 & $\left.21.7^{6}\right)$ & 0 & $\left.\left.88.9^{3}\right),{ }^{6}\right)$ & $1.0-4.1 \mu \mathrm{g} / 1$ \\
\hline D-dimer & 0 & $\left.\left.33.3^{4}\right),{ }^{5}\right)$ & 0 & $\left.\left.43.5^{4}\right),{ }^{7}\right)$ & 0 & $\left.\left(100^{5}\right),{ }^{7}\right)$ & $0 \quad-450 \mu \mathrm{g} / 1$ \\
\hline
\end{tabular}

This phenomenon has also been reported in a number of other cancer types (14-16). The elevated thrombinantithrombin III levels are consistent with an earlier study on this topic, in which thrombin-antithrombin III was considered a marker of malignant gynaecological disease (17). In general, an explanation for the activation of blood coagulation in tumours is thought to be a direct interaction of the coagulation factors with tumour cells $(18,19)$ or an indirect production of cytokines $(20)$. The evidence for both of these etiologies are however based on immunohistological investigations. An alternative, well-documented explanation is the evidence for the production of "cancer procoagulants", which have been shown to be produced by a large number of cell lines tested (21).

We calculated the D-dimer/thrombin-antithrombin III ratio and the $D$-dimer/prothrombin fragment $1+2$ ratio as arbitrary measures for the balance of the fibrinolysis/ coagulation system. Both ratios were increased in favour of fibrinolysis, being the highest in patients with metastases. The D-dimer/prothrombin fragment $1+2$ ratio showed a more pronounced increase than that of D-di- mer/thrombin-antithrombin III, probably because prothrombin fragment $1+2$ and thrombin-antithrombin III differ in production and elimination rates. Fibrinolysis seems to dominate over the coagulation system, therewith possibly preventing thrombotic events. Nevertheless, when the quantities of fibrinolysis and coagulation are enhanced the risk for such an event may be increased $(1-3,22-24)$.

In conclusion, it is not possible to differentiate between a benign and a malignant process on the basis of the constituents studied. The haemostasis quantities seem, however, to give an indication of the existence of metastases in patients suspected of malignant gynaecological tumours, although we are aware that the studied patient groups are rather heterogeneous. Therefore a follow-up study is ongoing focussing on the more frequent gynaecological cancer types e.g. ovarian cancer and cervix cancer. Moreover, more research will be necessary to evaluate the clinical impact of the elevated level of the fibrinolysis/coagulation balance in patients with the mentioned gynaecological cancer types.

\section{References}

1. Prandoni P, Lensing AWA, Büller HR, Cogo A, Prins MH, Cattelan AM, et al. Deep-vein thrombosis and the incidence of subsequent symptomatic cancer. N Eng J Med 1992; 327:1128-33.

2. Dvorak HF. Thrombosis and cancer. Hum Pathol 1987; 18:275-84.

3. Rickles FR, Edwards RL. Activation of blood coagulation in cancer: Trousseau's syndrome revisited. Blood 1983; 62:1431.

4. van Wersch JWJ, Tjwa MKT. Coagulation/fibrinolysis balance and lung cancer. Haemostasis 1991; 21:117-23.

5. Edwards RL, Rickles FR, Moritz TE, Henderson WG, Zacharski LR, Forman WB, et al. Abnormalities of blood coagulation tests in patients with cancer. Am J Clin Pathol 1987; 88:596-602.

6. Zacharski LR, Costantini V. Tumor cells and their procoagulant properties. Biomed Prog 1992; 404 (5):44-8.

7. Edwards RL, Morgan DL, Rickles FR. Animal tumor procoagulants: registry of the subcommittee on haemostasis and malignancy of the Scientific and Standardization Committee International Belt Society of Thrombosis and Haemostasis. Thromb Haemost 1990; 63:133-8.

8. Kwaan HC. Editorial: Fibrinolysis and cancer. Biomed Progr 1992; 4 (5):49-51.

9. Edwards RL, Rickles FR. Hemostatic alterations in cancer patients. In: Honn KV, Sloane BF, editors. Hemostatic mechanisms and metastasis. Boston: Martinus Nijhoff, 1984:343. 
10. Belt RJ, Lcite $C$, Haas $C D$, Stephens RL. Incidence of hemorrhagic complications in patients with cancer. J Am Med Ass 1978; 239 (24):2571-4.

11. Sun NC, McAfee WM, Hum GJ, Weiner JM. Hemostatic abnormalities in malignancy, a prospective study in one hundred eight patients. Part 1, Coagulation Studics. Am J Clin Pathol 1979; 71:10-6.

12. Hagedoorn AB, Bowie EJW, Elveback LR, Owen CA. Coagulation abnormalities in patients with inoperable lung cancer. Mayo Clin Proc 1974; 49:647-53.

13. Åstedt B, Svanberg L, Nilsson IM. Fibrin degradation products and ovarian tumours. Br Med J 1971; 4:458-9.

14. Svanberg L, Åstedt B, Gynning I, Nilsson IM. Fibrin degradation products during postoperative radiotherapy of ovarian carcinoma. Acta Obstet Gynec Scand 1973; 52:141-5.

15. van Duijnhoven EM, Lustermans FAT, van Wersch JWJ. Evaluation of the coagulation/fibrinolysis balance in patients with colorectal cancer. Haemostasis 1993; 23 (2):168-72.

16. McCulloch P, Nieuwenhuizen W, Douglas J, Lowe GDO, George WD. Coagulation disturbance in cancer of the breast and colon measured with specific monoclonal antibody enzyme immunoassay for fibrin-fibrinogen degradation products. Haemostasis 1990; 20:73-80.

17. Tatra G, Reinthaller A. Elevated thrombin-antithrombin III complex concentrations in patients with gynaecological malignancy. Klin Wochenschr 1991; 69:124.

18. Wojtukiewicz MZ, Zacharski LR, Memoli VA, Kisiel W, Kudryk BJ, Rousseau SM, Stump DC. Abnormal regulation of coagulation/fibrinolysis in small cell carcinoma of the lung. Cancer 1990; 65:481-5.

19. Wojtukiewicz MZ, Zacharski LR, Memoli VA, Kisiel W, Kudryk BJ, Rousseau SM, Stump DC. Malignant melanoma: interaction with coagulation and fibrinolysis in situ. Am J Clin Pathol 1990; 93:516-21.

20. Wojtukiewicz MZ, Zacharski LR, Memoli VA, Kisiel W, Kudryk BJ, Rousseau SM, Stump DC. Indirect activation of blood coagulation in colon cancer. Thromb Haemost 1989; 62:1062-6.

21. Gordon SG, Franks JJ, Lewis BJ. Comparison of procoagulant activities in extracts of normal and malignant human tissuc. $\mathrm{J}$ Natl Cancer Inst 1979; 62:773-6.

22. Rahr HB, Sørensen JV. Venous thromboembolism and cancer. Blood Coagul Fibrinolysis 1992; 3:451-60.

23. Kies MS, Posch JJ, Giolma JP, Rubin RN. Hemostatic function in cancer patients. Cancer 1980; 46:831-7.

24. Davis RB, Theologides A, Kennedy BJ. Comparative studies of blood coagulation and platelet aggregation in patients with cancer and nonmalignant diseases. Ann Int Med 1969; 71 (1):67-80.

Dr. J. W. J. van Wersch

De Wever Hospital

P. O. Box 4446

NL-6401 CX Heerlen

The Netherlands 


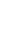

